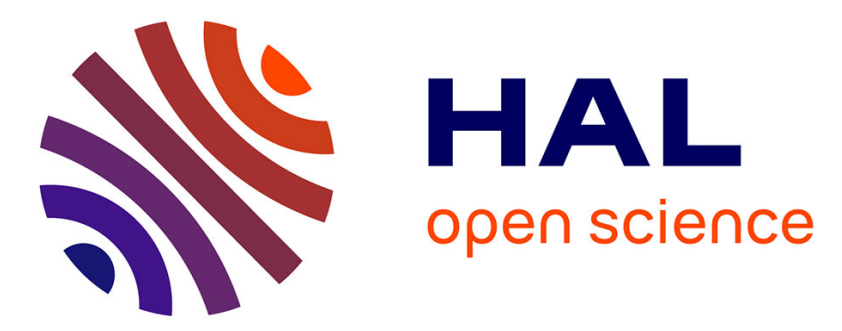

\title{
The influence of multi-product production strategy on factory induced bullwhip
}

\author{
Andrew Potter, Denis R Towill, Tillmann Boehme, S M Disney
}

\section{To cite this version:}

Andrew Potter, Denis R Towill, Tillmann Boehme, S M Disney. The influence of multi-product production strategy on factory induced bullwhip. International Journal of Production Research, 2009, 47 (20), pp.5739-5759. 10.1080/00207540802146148 . hal-00513039

\section{HAL Id: hal-00513039 \\ https://hal.science/hal-00513039}

Submitted on 1 Sep 2010

HAL is a multi-disciplinary open access archive for the deposit and dissemination of scientific research documents, whether they are published or not. The documents may come from teaching and research institutions in France or abroad, or from public or private research centers.
L'archive ouverte pluridisciplinaire HAL, est destinée au dépôt et à la diffusion de documents scientifiques de niveau recherche, publiés ou non, émanant des établissements d'enseignement et de recherche français ou étrangers, des laboratoires publics ou privés. 


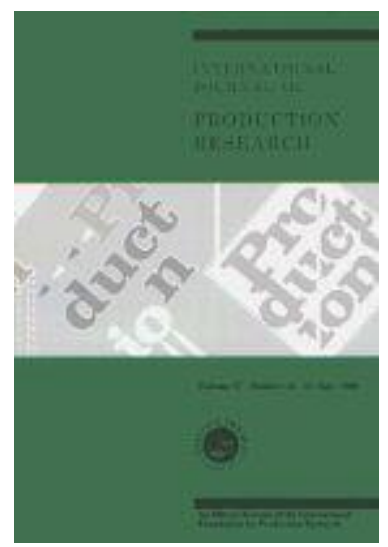

The influence of multi-product production strategy on factory induced bullwhip

\begin{tabular}{|r|l|}
\hline Journal: & International Journal of Production Research \\
\hline Manuscript ID: & TPRS-2007-IJPR-0799.R1 \\
\hline Danuscript Type: & Original Manuscript \\
\hline Author: & 07-Apr-2008 \\
\hline Komplete List of Authors: & $\begin{array}{l}\text { Potter, Andrew; Cardiff University, Logistics Systems Dynamics } \\
\text { Group } \\
\text { Towill, Denis; Cardiff University, Logistics Systems Dynamics } \\
\text { Group; Cardiff University, Logistics Systems Dynamics Group } \\
\text { Boehme, Tillmann; Waikato University, Waikato Management } \\
\text { School } \\
\text { Disney, S M; Cardiff University, Logistics Systems Dynamics Group }\end{array}$ \\
\hline Keywords: & $\begin{array}{l}\text { BATCH PROCESSING, BULLWIP EFFECT, SUPPLY CHAIN } \\
\text { MANAGEMENT, MANUFACTURING STRATEGY, OPERATIONS } \\
\text { STRATEGY }\end{array}$ \\
\hline Keywords (user): & Minimum Reasonable Bullwhip, Shared resources \\
\hline
\end{tabular}

\section{s) ScholarONE" \\ Manuscript Central}


The influence of multi-product production strategy on factory induced bullwhip

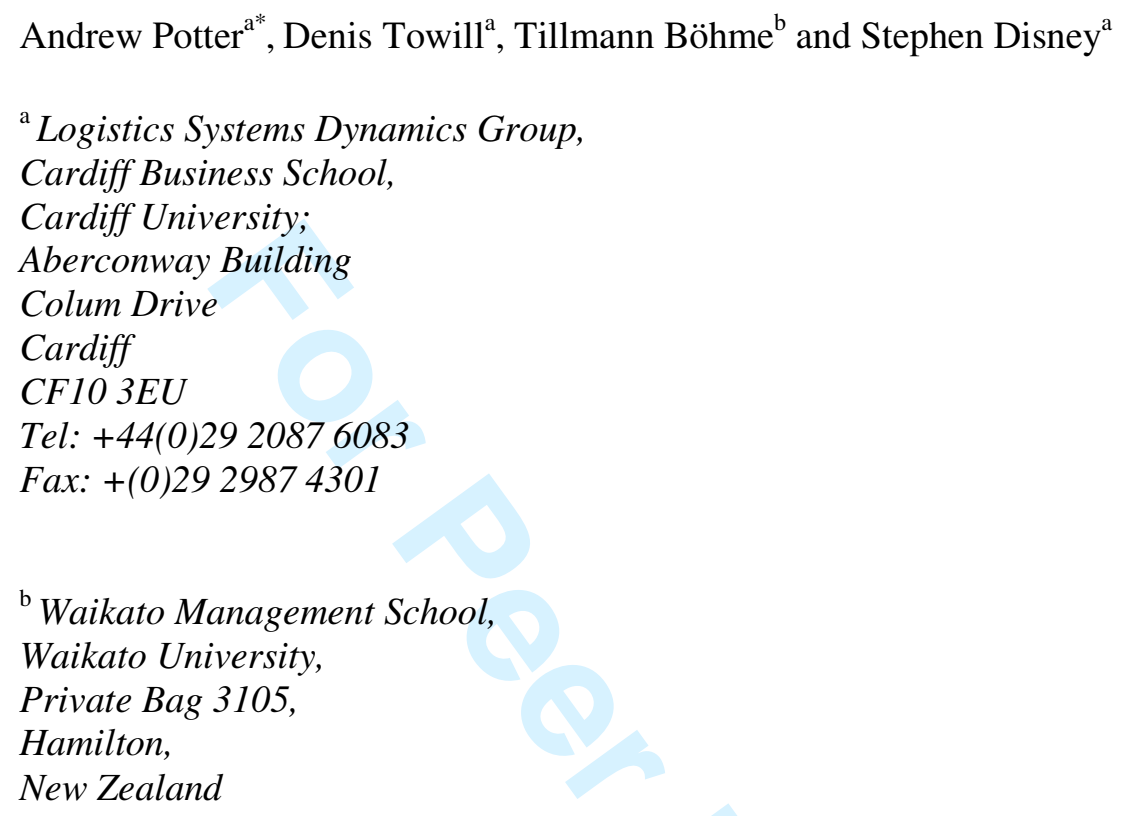

Abstract

Conventional thinking suggests bullwhip should necessarily be minimised within the supply chain. While this may be good practice where no constraints exist, in reality companies have shared resources and capacity limits that affect their ability to do this. Consequently, there is an influence upon their production strategy. This can introduce some bullwhip into the supply chain but, managed effectively, can actually be useful. We call this useful strategy "Minimum Reasonable Bullwhip" (MRB). The aim of this paper is to examine the relationship between production strategy and bullwhip where constraints exist. In doing so, three case studies are presented where distinct clusters of product types exist, each with different observed levels of bullwhip. By considering total supply chain costs, we explain why these clusters exist. The paper contributes to the literature by challenging the contention that bullwhip should always be minimised, given the importance that it is important to achieve performance objectives across the product range. It also identifies areas for future research to extend the MRB concept.

Keywords: Minimum Reasonable Bullwhip, multi-product, batching, shared resources

\section{Word Count: 7150 (including appendices and references) 5210 (main body only)}

\footnotetext{
*Corresponding author. Email: PotterAT@Cardiff.ac.uk
} 


\section{Introduction}

Bullwhip as coined by Lee et al. (1997) is still an extensive and expensive problem in real world supply chains. But under its old guise of demand amplification, it was a phenomenon well documented firstly in the USA by Jay Forrester (1961), and secondly in the UK by Jack Burbidge (1984). Possible solutions for reducing bullwhip were also proposed by Forrester (based on a DYNAMO simulation model) and by Burbidge based on his shop floor observations supplemented by industrial engineering analysis. Since those early days the Forrester and Burbidge ideas have been greatly extended and further refined. They have also been successfully applied in a number of supply chain scenarios, with a significant reduction observed in the bullwhip effect. So it is clear that proven solutions to bullwhip are available for those businesses wishing to reduce costs and to increase customer service levels.

Rather than focus on minimising bullwhip, this paper develops the concept of Minimum Reasonable Bullwhip (MRB). We argue that there may often be a need to introduce a small amount of additional bullwhip into the supply chain, particularly given the presence of batching and a multi-product scenario. Provided this modest bullwhip is introduced to enable performance targets to be met across all products, it can be considered useful and thus represents a MRB. Again, actual bullwhip may be higher, representing a mismatch between the ordering policy and customer requirements for that product. This is also likely to impact on other performance metrics.

It may be that within any one organisation various clusters of products may have quite different types of supply chains, depending upon either the customer or product type (such as the runner, repeater or stranger classification system, see Parnaby, 1988). Therefore each cluster may have its own value of bullwhip rather than a uniform value for the organisation as a whole. The aim of this paper is to establish relationships between production strategies and bullwhip and subject to the performance regime in the supply chains. In particular, we focus upon scenarios where a number of different products share capacity constrained assets. It is not the intention to try and provide quantification as to low and high levels of MRB; these values are unique to every organisation. To achieve the aim, we utilise a case study approach.

\section{Bullwhip Reviewed}

Bullwhip can be defined as the increase in variability of demand information as it passes along the supply chain. It is caused by events internal to the supply chain, rather than external factors. A full review of the history of bullwhip can be found in Towill et al. (2007). Lee et al (1997) suggest that there are at least four main causes of bullwhip within supply chains. They specifically identify demand signal processing (allied with non-zero lead times), order batching, rationing and gaming, and price fluctuations as potential troublemakers. However, this is an underestimate of the number of sources, since Geary et al (2005) have described ten such triggers, any one of which is sufficient to cause substantial on-costs within the delivery 
pipeline. This paper is particularly concerned with the impact of order batching, which has also been termed the Burbidge effect (Towill, 1997).

In his seminal work relating to production systems, Burbidge (1984) argues that batching due to Economic Batch Quantity (EBQ) policies will result in 'interference' between value streams queuing up to utilise the shared resources. Also, incoming demand will be excessively variable due to repeated batching within the supply chain as each echelon applies their own set of EBQ rules. His findings are summarised in Table 1. This effect can be clearly seen in Hejazi and Hilmola (2006) through their empirical examples from the furniture and electronics sectors. Therefore, Burbidge advocates the separation of value streams into independent flows.

\section{Take in Table 1 here}

An alternative viewpoint (Towill, 1992) is that, whenever possible, batching within the supply chain should occur at one level only. If different products can then be phased optimally, the Burbidge effects can be minimised (but not eliminated). Therefore, the 'Batch of One' concept is a reasonable but not realistic target for manufacturers. Instead, the producer should enable completion in small batches with rapid switchover times. By introducing batching, the frequency of production decreases, possibly to weekly or less often, as other products must also use the same assets. However, delivery to the customer remains daily. Hence, companies need to balance between variable, frequent customer demand and variable, infrequent supply from manufacturing while maintaining performance objectives for all products.

\section{Contribution of the Present Paper}

In terms of the relationship between bullwhip and batch size, there have been a number of theoretical studies in the literature and considering a range of ordering policies including lot sizing (Pujawan, 2004), (s, Q) systems (Kimura and Terada, 1981), (s, S) systems (Kelle and Milne, 1999) and (R, S) systems (Holland and Sodhi, 2004, Potter and Disney, 2006). One common theme in the literature is the need to reduce batch sizes as low as possible, ideally aiming towards a 'Batch of One' (Burbidge, 1981). However, there may be occasions where, for technical, economic or social reasons, this may not be desirable.

Another feature of the existing literature is that the findings are mainly drawn from simulation modelling with only a single product flowing through the supply chain. Whilst this simplifies the simulation process, there are many instances in reality where different value streams within an organisation share resources and assets. Such a situation clearly impacts on what may be regarded as a target for bullwhip reduction. Some modelling of multi-product scenarios has taken place (for example, see Iyer and Jain, 2003), but this does not explicitly evaluate bullwhip. An exception to this is Holmström (1997), who shows that a factory smoothes the demand signal for high volume products while introducing significant amplification for low volume products. However, no insights are provided as to why the company has adopted this production strategy. 
The specific contribution of this paper is to develop and examine the concept of MRB within an industrial context. A key element is the examination of value streams involving batch production using shared assets. We go further than Holmström (1997) by questioning why companies adopt particular production strategies given the influence of bullwhip on system performance. In doing so, use is made of empirical case studies which demonstrate how bullwhip varies for different pipelines. A common underlying theme is that all pipelines meet their required performance objectives. As van Donk and van der Vaart (2005) identify, there is little research relating to cases of shared resources within supply chains. Therefore, this paper provides valuable insights into the management of the bullwhip effect within these real-world environments.

\section{Supply Chain Cost Sources}

In considering performance objectives, we adopt the approach put forward by Fisher (1997). As illustrated in Figure 1, he decomposes supply chain performance into two components. These are acquisition costs and market mediation costs. Acquisition costs tend to be associated with the physical production and distribution of the goods, and can generally be calculated quite readily. Marketability costs are more intangible and encompass issues such as product quality, customer service and the relative importance of a customer to the company (termed 'throughput cost' in this paper).

\section{Take in Figure 1 around here}

Having identified these costs, Fisher then proceeds to conceptually link this equation to value stream design. Developing the ideas of Fuller et al. (1993), he suggests providing efficient supply chains for functional products and responsive supply chains for innovative products. There is a growing body of literature studying the importance of matching supply chains to the nature of the product and the process by which this can be achieved. Christopher and Towill (2001) identify three different approaches which can be adopted to pragmatically combine efficient and responsive value streams:

- Pareto/80:20 curve; to identify which products should be classed as efficient and those that require a responsive value chain

- De-coupling point, or postponement; where products are tailored to a customers requirements as and when this is known

- Base and surge demand; distinguishing between functional and innovative products so as to schedule production more effectively.

They further show that each such pathway can help provide significant improvements to supply chain performance.

\section{Practical Delivery Strategies}

The literature also provides a number of examples where variations on these approaches have been identified as appropriate:

- In apparel, Abernathy et al. (2000) demonstrate the importance for retailers of determining inventory policy at a stock keeping unit level. Warburton and Stratton (2002) apply a similar approach for manufacturing, suggesting that 
offshore production is better suited to functional products while innovative products should be manufactured close to the market they serve.

- Childerhouse et al. (2002) use the example of lighting products to demonstrate how the nature of the value chain, including production strategy, evolves during the course of a product's life cycle. Early on in the cycle, service is paramount (reflected through marketability costs), while maturity and saturation sees acquisition cost become more important. Finally, when a product declines, service again becomes the main order winner.

- With toys, the majority of manufacturers still operate to a traditional mass production model despite different retail approaches existing (Wong et al., 2005). In the case of Lego, there is some difference in production strategy depending upon where the product is in its life cycle, as illustrated in Table 2. However, this strategy provides a mis-match some retailer demands resulting in order fill rates typically as low as between 50 and 80\% (Wong and Johansen, 2006).

\section{Take in Table 2 around here}

While there are these examples of matching production strategies to product clusters, there is been little consideration as to the consequential impact on bullwhip. Some data for Lego is available (El-Beheiry, et al., 2004), but this is both aggregated and considers only the distribution network and not production. Furthermore, as noted by van Donk and van der Vaart (2005), there is little research relating to cases of shared resources within supply chains. Hence, this paper aims to address these gaps, by giving insights into how the use of different production strategies within a capacity constrained system can influence the levels of bullwhip.

\section{Investigative Methodology Adopted}

Much of the previous research on bullwhip and production strategies within supply chains uses simulation as a tool for investigation. The focus is on a single product as the "unit" that flows through the supply chain. Once a number of products are introduced, there are difficulties with exploiting simulation as the results tend to be dependent on the decision rules modelled. Results, such as those in Metters (1997), are likely to be optimistic (that is, they may considerably underestimate the true cost of bullwhip) for real-world industrial situations. Simulation is sometimes inappropriate because of the need to understand the context behind production decisions. Given the aim of this paper, this context is important as we are examining why different bullwhip levels exist within a company for different clusters of products. Therefore, we adopt a multiple case study approach, using examples from the grocery sector in the UK and New Zealand, and the steel industry in the UK.

An important element of case study research is to ensure rigour in the research process (Stuart, et al., 2002). To achieve this, each case investigation was based on the Quick Scan Audit Methodology (QSAM, Naim, et al., 2002). This brings together three complementary tools - process mapping, archival data and interviews. The aim is the understanding and documenting of the system under investigation, as well as providing opportunities for triangulation. A summary of the data collected from each 
case can be found in Table 3, and more details can be found in the Appendices. The analysis phase involved the whole research team from the Quick Scan. This additionally enables analyst triangulation and reduces the risk of bias in the findings (Patton, 2002).

\section{Take in Table 3 around here}

In the context of this paper, a key part of the analysis was the review of archival data. Time series graphs of customer orders, production decisions and inventory levels were developed and bullwhip levels calculated (as appropriate) using the coefficient of variation $(\mathrm{CoV})$ for each data set. Because this represents the standard deviation of the data divided by the average value, it was possible to make a comparison between time series with different average values. From this analysis, key clusters were identified. Reference was then made back to the other data sources to identify the reasons behind these differences. These were then codified against the Fisher (1997) equation for supply chain costs to provide consistency in the analysis.

The paper now presents the findings from each of the case studies, along with an explanation for the behaviour observed. Consideration is firstly given to the examples from the grocery sector in the UK and New Zealand, before moving on to the steel supply chain. Opportunities for cross case comparisons are exploited in section 10.

\section{The UK Grocery Supply Chain}

The case being studied here is a manufacturer of soft drinks and their supply chain with two different retailers. Finished goods pass from the factory to a distribution centre (DC) owned by the retailer and then on to retail outlets. Retailer A represents the largest customer of the soft drinks manufacturer, accounting for around $30 \%$ of their total sales and about 200 product lines. By contrast, Retailer B represents around $10 \%$ of all sales of the soft drinks manufacturer, with around 130 product lines. For both retailers, 3 product lines were studied, representing typically high, medium and low volume products. The main marketplace difference between the products is that Retailer A adopts an Every Day Low Pricing (EDLP) principle while Retailer B makes use of promotions.

Turning to the acquisition process, for both retailers, orders are generated by an inventory control system. However, the manufacturer operates a vendor managed inventory (VMI) system with Retailer A. This gives the opportunity to reallocate inventory depending upon stock levels at both DCs and the manufacturer. The production planning process is driven by the ERP system. Production is planned around a batch size of 7,500 cases, although sometimes 'half batches' of 3,750 cases are made. Typically, the target is to hold 1.5 weeks of finished goods stock at the factory, generally to maintain customer service. In terms of production, there is no dedication of the assets to either a particular product or customer. For Retailers A and B, customer service levels are $99.1 \%$ and $99.2 \%$ respectively.

Figure 2 compares the bullwhip and inventory variance for both retailers. Inventory variance is based on the change to net stock levels, via the inventory balance equation, as actual inventory levels were not available. What can be seen is that there are two 
distinct clusters with Retailer A having a higher level of bullwhip but lower inventory variance. There are a number of factors behind this. Firstly, there is EDLP, and so variability within the retailer's orders is relatively low. This can be seen in Figure 3, where the cusum graph has much less variability than for Retailer B. This reduces uncertainty in respect of likely production requirements and can effectively facilitate level scheduling.

Second, with Retailer B, the potential for promotions creates uncertainty. Consequently, if there is pressure on production capacity due to a surge in demand for Retailer B's products, the production scheduler can review finished goods levels and decide whether production will actually be required of Retailer A's products. If not, then production can be either brought forward or pushed back so as to compensate for the missed week. An example is indicated in Figure 3. In effect, the base and surge approach discussed in Christopher and Towill (2001) is used, but with 'surge' allocated production capacity first. This introduces bullwhip into the supply chain of Retailer A's products. However, the process is well controlled and provides the opportunity to maintain service levels for other customers. A final factor is the visibility afforded through VMI which enables the manufacturer to take a full account of inventory at the DCs as well as within the factory.

\section{Take in Figure 2 around here}

\section{Take in Figure 3 around here}

Turning to the lower inventory position for Retailer A, this can be explained by several factors. As with bullwhip, the low level of demand variability means that the level of safety stock required in achieving a given service level is much less than for Retailer B. Also, the visibility from VMI effectively provides extra buffer stock as the inventory at DCs can be observed. This modus operandi permits the VMI controller to redistribute orders, so as to balance inventory better and minimise stockouts at the DCs. Additionally, there is the close relationship between the batch sizes and average demand which accounts for the low inventory variability. Hence to summarise, in this case, the soft drinks manufacturer is willing to accept a small amount of bullwhip for the VMI customer in order to provide flexibility in production to enable the performance objectives of all customers to be met.

\section{The New Zealand Grocery Supply Chain}

The second example is taken from the New Zealand grocery sector. The company produces a broad range of imperishable food products although we focus on one tinned product. Perishable suppliers for this particular product are mainly locally based. However, most of the other ingredients, such as spices, are imported. Once the food and ingredients are processed, the unlabeled tin is stocked in a warehouse. After an order is received, the tin is labelled and transported to the customer. The company currently operates with a VMI distribution strategy with their high volume customers.

Unlike the other examples in this paper, the manufacturer does not generate production requests for each customer individually, but instead allocates stock once orders are received. In effect, orders do not penetrate beyond the finished goods stock. 
However, as noted previously, the introduction of VMI with certain customers creates two different distribution strategies, which then has a consequential impact on production. So we focus on how demand variability differs between VMI and nonVMI customers. The Pareto analysis of 9 months order data (in Figure 4) shows that $20 \%$ of the customers account for $83 \%$ of volume, and hence we focus upon these companies only. 7 are engaged in the VMI programme, and Table 4 provides a comparison of their key statistics with non-VMI customers.

\section{Take in Figure 4 around here}

\section{Take in Table 4 around here}

What Table 4 shows is that the variability of incoming orders experienced for VMI customer is much reduced when compared to that for the non-VMI customers. By managing customers stock, the case company moves away from batched orders to smaller, more frequent deliveries. To some extent, this is also reflected in the total logistics costs. For many of the non-VMI customers, the additional transport and ordering costs consequent upon smaller, more frequent delivery outweigh the inventory and production cost benefits. In effect, the company is heading towards the 80:20 approach described in Christopher and Towill (2001), where VMI is used for efficient supply chains. Because production is aggregated across all customers, the bullwhip actually comes out higher for VMI customers. Even then, there is little amplification which indicates that the company is using customer information effectively in production planning.

\section{The UK Steel Supply Chain}

The final example is drawn from the UK steel industry, and focuses upon a steel producer and their relationship with 2 customers. Orders are received many weeks in advance, and detail the specification, delivery week and quantity. These orders are then used to plan raw material requirements. The main raw material is hot rolled coil (HRC), sourced locally. The main physical flows are depicted in Figure 5. Once allocated to a specific order, the HRC is launched. The first stage is to test the quality of the raw materials, and about $20 \%$ of steel fails to make the specification. The good steel is then rolled to the correct thickness and width before being coated. A further yield loss of around 10\% occurs here. Once in the warehouse, the material is available to despatch, with the exact delivery date determined by the customer. If there is insufficient steel to meet the order, additional material may be taken from other sources, either orders for other customers or by reworking some of the previously rejected steel.

\section{Take in Figure 5 around here}

To investigate the production strategies adopted and their impact on bullwhip, 18 products were studied in more detail. These were equally split across the two customers, with 3 products from each customer selected to represent high, medium and low volume lines. This classification was based on total despatched volume over a 2 year period. However, some of the products were only ordered for a relatively 
short period during the 2 years. The data on each of the products can be found in Table 5. Average weekly values and CoVs are calculated across the time window over which orders were placed rather than the 2 years.

\section{Take in Table 5 around here}

We first consider the difference in bullwhip between high, medium and low volume products. Generally, the variability in incoming demand decreases from high to low products, and bullwhip follows the same trend. This can be seen in Figure 6, which plots these two variables. The high volume products are ordered most weeks, and so production has to accommodate both changes in demand and any variations in yield that may occur. Orders for medium volume products are batched by the customers and so no further batching is required. However, yield loss needs to be accommodated. Finally, low volume products are ordered sporadically. Therefore, production has to be closely aligned with demand. This minimises the risk of holding inventory of unwanted finished goods.

\section{Take in Figure 6 around here}

In terms of bullwhip Table 5 shows that, for high and medium volume products, Customer X tends to have a greater level of bullwhip that Customer Y. With the high volume products, there are two related elements that are influencing the production strategy for Customer X. Firstly, no account for quality or yield losses appears to be made. The average weekly tonnage of launched HRC is much closer to average demand than for Customer Y. This is confirmed by the percentage of despatches from other sources. The steel producer is willing to do this as the Customer $\mathrm{X}$ is the largest customer and therefore takes priority both in production and distribution. In effect, a traditional 'base-surge' manufacturing strategy is deployed. Therefore, their products get scheduled first, thus guaranteeing on-time manufacture.

The second interesting feature is that inventory of high volume products tends to remain in the warehouse longer for Customer $\mathrm{X}$ as a greater percentage of products available for despatch during the required week (according to the order) are kept in stock until a later delivery week. While this helps offset some of the risk from not allowing for losses during production, the lack of a buffer does not have the same dampening effect as for Customer Y, and therefore increases bullwhip. The same is also true for medium volume products, particularly if products with similar average weekly orders/despatches are compared. Product G is particularly amplified as, although the volume over the 2 year period was low, the orders were concentrated into a short time frame and placed regularly, therefore effecting a low coefficient of variation for demand.

Overall, the steel producer chooses to accept a slightly higher level of bullwhip for Customer $\mathrm{X}$ by not taking account of yield and quality losses. Although there are higher stock levels for this customer (driven by the customer rather than the manufacturer), not including a buffer keeps these under control. Furthermore, making up any shortfalls from elsewhere can help to control total inventory. However, this also adds variability to the production process, therefore increasing bullwhip. 


\section{Assessing Bullwhip Implications}

In all of the above cases, it has been demonstrated that the choice of production strategy can have an impact on the level of bullwhip generated within the supply chain. In order to understand more about why manufacturers are willing to accept higher bullwhip levels for some customers/products, we refer back to the Fisher (1997) cost model described in Figure 1. Based on the data collected in our Quick Scans, Table 6 assesses the relative importance of acquisition costs to marketability costs in each of the cases.

As can be seen, the New Zealand grocery and UK steel cases place a greater emphasis on acquisition costs than on marketability costs. The New Zealand manufacturer of canned food predominantly produces functional products with a very long life cycle. These are suited to a lean supply chain strategy (Christopher and Towill, 2001), as implemented by the New Zealand manufacturer. Hence, the focus is on minimising the cost. Steel is a commodity product, and therefore it is important to minimise costs as much as possible. Marketability is less important; the manufacturing performance in terms of material ready for despatch on time was $53 \%$ for both Customers $\mathrm{X}$ and $\mathrm{Y}$. The case steel company is willing to accept some bullwhip in order to achieve production economies and inventory reduction. The UK grocery example places a greater emphasis on marketability costs due to the severe penalties imposed on suppliers if they fail to deliver a satisfactory level of service (Blythman, 2004).

\section{Take in Table 6 around here}

It is also important to consider the importance of the individual elements that make up total supply chain costs. Table 7 summarises these costs given the different production strategies deployed, with the most important individual cost underlined. The implications for bullwhip, and the internal factors that affect this, are also identified therein. In the case of the UK grocery supply chain, the company is willing to accept bullwhip as this results from desired flexibility in the VMI supply chain. Consequently, it is possible for the non-VMI supply chain to also achieve its service targets and therefore reduce the marketability costs as much as possible.

\section{Take in Table 7 around here}

In the case of New Zealand grocery, short/missed deliveries is actually the most important cost, despite acquisition costs overall being more important. This focus on service reinforces the use of VMI for large customers, although the overall importance of acquisition costs ensures the products still remain cost effective. In UK steel, production costs dominate decision making, with inventory costs also considered important. However, as the case details have shown, inventory levels are driven as much by the steel producer as their customers. It is also interesting to note that, compared to the grocery cases, throughput costs appear to hold more weight as Customer $\mathrm{X}$ receives priority in production planning. In all cases, two internal factors that can affect the level of bullwhip generated are the production batch sizes and capacity allocation between different customers/products. In the grocery supply chain, VMI also influences the level of bullwhip, by helping to smooth incoming demand (and therefore reducing the denominator of the bullwhip calculation). 


\section{Discussion and Need for Further Research}

Through the case studies above, we have considered the implications for bullwhip that arise from the application of different production strategies to the value streams present within a business. In doing so, a key feature has been the ability of the case companies to continue to satisfy (rather than maximise) performance objectives for all customers rather than maximise our performance for the select few. A motivation behind the research is the general focus within the current research literature on single value streams operating in isolation from others. In reality, a supply chain incorporates multiple value streams that often share resources, and this area appears to be under-researched.

The case examples clearly demonstrate that there can be noticeable differences in the level of bullwhip generated for clusters of products. However, in the cases we have studied this is no detriment to overall supply chain performance. Bullwhip costs represent one part of total supply chain costs, and a businesses objective is to minimise total costs as much as possible. Therefore, increased bullwhip is acceptable, providing it is understood and controlled. Consequently, we introduce in this paper the term Minimum Reasonable Bullwhip (MRB). This represents the relatively small but helpful bullwhip required to achieve the performance objectives pertinent to that pipeline given the imposed constraints. Grünwald and Fortuin (1992) introduce a similar concept with Minimum Reasonable Inventory (MRI), which they define as the lowest level of inventory appropriate for a particular supply chain in order to maintain performance targets. As with MRI, MRB sets a realistic target for the supply chain to adhere to, rather than attempting to justify excessive bullwhip. This challenges the conventional wisdom that businesses should always look to minimise bullwhip. What is interesting is that in all three cases investigated the highest levels of bullwhip are generated by products with larger volumes. This contrasts with the results obtained by Holmström (1997) for a European confectionary supply chain.

Scope exists for extensive further research within this area. The UK grocery case enabled some initial insights into the relationship between MRB and inventory variability (Figure 2). However, the quality of available data meant that it was not possible to fully explore this idea further in the other cases. Another topic for further investigation is to compare the above findings with one where the decoupling point is deployed, so as to cover the three lean/agile scenarios in Christopher and Towill (2001). Finally, there is scope for translating the above cases into simulation models using the approach described in Towill (1996). This may provide further insights into MRB and the factors that affect it.

\section{Conclusions}

This paper has investigated the trade off between bullwhip and inventory in a multiproduct environment where some batching is inevitable. The aim was to demonstrate that, in meeting performance objectives of the complete pipeline, there may be the need to introduce additional bullwhip into the supply chain. In particular, reference was made to total supply chain costs, using the concept of acquisition and marketability costs as discussed by Fisher (1997). 
Through three case studies (involving 10 clusters of products and time series data for 58 products/customer), an attempt has been made to validate this proposition. By studying the supply chains associated with different customers and product volumes, distinct clusters of results were found. These were then further analysed to identify the rationale behind why these companies are willing to accept more bullwhip for certain products than others. A key element of the findings is that, by accepting higher bullwhip levels, it is possible in well designed and operated supply chains to satisfy delivery performance objectives across a wider range of customers.

Where this paper contributes to the literature is through challenging the contention that some bullwhip and inventory holding is always bad for the supply chain. In satisfying performance objectives for all products, it may be that a controlled amount of one or the other is required. The term 'controlled' is important in this context as excessive inventory holding or rampant bullwhip will still be destructive to the supply chain (Metters, 1997). In terms of managerial implications, we have highlighted the benefits that can be obtained from different inventory management control strategies and how, when combined, they enable performance objectives for all products to be maintained.

\section{Appendix A - Detailed method for UK grocery case}

In conducting the research, a key objective was to compare the performance of a VMI and non-VMI supply chain. Initially, it was hoped to compare one supply chain before and after VMI implementation. However, in consultation with the manufacturer, it was found that availability of data on the relationship with the retailer before the implementation of VMI was limited. Therefore, the results were compared with those for a non-VMI retailer where the product range was comparable and supplied through similar distribution channels. Three products with a high, medium and low volume of sales were also selected to provide analysis at product level. The retailers and products are profiled in Table A1.

\section{Take in Table Al around here}

The data collection process involved the author leading a team of two other researchers on a two day visit to the main offices of the manufacturer in order to collect the necessary data. The main data sources in the QSAM were:

- Process mapping - this focussed upon the information flows within the case study company. It was carried out through interviews and observation, the latter to ensure that the description tallied with what was actually done.

- Archival data - mostly this came from the manufacturer, although Electronic Point of Sale (EPOS) data from the VMI retailer was also obtained. The only exception was for the measures of customer service, where a change in the recording procedure meant there was no data available before October 2003. Inventory data was unavailable as the ERP system did not record historic values.

- Interviews - these were used to obtain opinions on both value streams, and the production strategy adopted by the manufacturer. Details of interviewees are shown in Table 3. 
Initially, the archived data was plotted as time series and cusum graphs. The time series graphs helped to visualise the demand amplification taking place within the supply chain. The cusum graphs were useful in ensuring that there was consistency between the EPOS, retailer order and production data, so that at the end of the time period, the amount produced was similar to the amount sold at the retailer. To complement the graphs, bullwhip across the manufacturer was calculated using the coefficients of variation for retailer orders and production.

Data on actual inventory levels could not be obtained from the manufacturer. Therefore, net stock levels were calculated using the equation

Net stock ${ }_{t}=$ Net $_{\text {stock }}{ }_{t-1}+$ Production $_{t}-$ Retailer orders $_{t}$

Net stock in week $\mathrm{t}=0$ was set at zero. From this time series, the mean absolute deviation was calculated as a measure of the variability in inventory levels.

\section{Appendix B - Detailed method for New Zealand grocery case}

The main objective of this application of the QSAM was to benchmark supply chain integration practices of three value streams with previous QSAM conducted in New Zealand, UK, Germany and Thailand. The outcome of the benchmarking process highlighted that the overall level of supply chain integration was very good; in fact the three value streams studied in depth are the best of fourteen examined in New Zealand to-date. From a more global perspective, the focal company is amongst the top ten percentile of 82 value streams studied to-date. In particular, the QS team noted operational excellence in procurement, supplier relationship management, manufacturing and logistics.

Subsequently to the QSAM, a further request for data was made from the company. This provided specific information for one product that the company made, and included both customer order and production information. This product represents the biggest selling product for the case company in the domestic market. In total, time series data over a 9 month period for 165 customers was received. Many of these customers ordered less than 10 cases of the product during this time. Therefore, a Pareto analysis was carried out, and this showed that 34 customers (20\% of the population) accounted for $83 \%$ of the volume.

Therefore, the analysis was limited to these customers only, and the CoV of orders received for each customer calculated. Further contact was made with the company to identify the customers engaged in VMI to enable clustering to occur. The CoV for production is based around total production, as differentiation by customer occurs upon despatch from the company. Where no production was recorded in a week, a zero was entered into the time series to provide consistency with the customer order data and also the other case studies in this paper. 


\section{Appendix C - Detailed method for UK steel case}

The data for this case study is taken from a Masters degree dissertation (Bowles, 2004), which was supervised by one of the authors. However, the analysis contained in this paper is solely the responsibility of the authors.

The purpose of the dissertation study was to examine whether bullwhip was occurring within the case study steel works, and to examine the causes of this. The first stage of the QSAM was to develop a process map, by following the products through the manufacturing plant. The nature of the final products meant that a range of different routes through the manufacturing process were possible. Next, a runner/repeater/ stranger analysis was carried out to identify appropriate products to analyse. This was based on total volumes despatched over a 2 year period to two of the main customers of the steel works. For each category, 3 products from each customer's order book were selected for further analysis (giving a total of 18 different products).

Time series data for each of these products was then extracted from the computer systems used within the case company. Because these systems were functional in nature, it was then necessary to align the data to ensure like was being compared with like. The data was then presented both schematically and as time series graphs to provide a visual verification as to the accuracy of the data. The schematic diagram particularly highlighted the aggregate flow of products through the processes, including any rework, and customer deliveries. From this, bullwhip was then calculated for each product. The time series graphs indicated that while some products were ordered throughout the 2 year period, others were only ordered for a shorter time. Therefore, the coefficients of variation were only calculated over the time period from the first data point until the last data point.

Finally, once the data had been analysed, interviews were carried out to understand the causes of bullwhip within the steel company. One issue was a general lack of understanding of bullwhip within the case company. Therefore, all the interviews started with an explanation of the work and the theory of bullwhip to enable the participants to input into the causes. 


\section{References}

Abernathy, F.H., Dunlop, J.T., Hammond, J.H. and Weil, D., 2000. Control your inventory in a world of lean retailing. Harvard Business Review, 78 (6), 169-176.

Blythman, J., 2004. Shopped. London: Fourth Estate.

Bowles, D., 2004. A study of demand amplification in relation to the food can supply chain. Masters Dissertation, Cardiff University.

Burbidge, J.L., 1981. The new approach to production. Production Engineer, 40 (12), 769-784.

Burbidge, J.L., 1984. Automated production control with a simulation capability. IFIP Working Paper WG5(7), Copenhagen.

Childerhouse, P., Aitken, J. and Towill, D.R., 2002. Analysis and design of focused demand chains. Journal of Operations Management, 20, 675-689.

Christopher, M. and Towill, D.R., 2001. An integrated model for the design of agile supply chains. International Journal of Physical Distribution and Logistics Management, 31 (4), 235-246.

El-Beheiry, M., Wong, C.Y. and El-Kharbotly, A., 2004. Empirical quantification of bullwhip effect (with application to a toy supply chain), Proceedings of the 13th International Working Seminar on Production Economics, Igls, Austria, Vol. 3, 83-96.

Fisher, M.L., 1997. What is the right supply chain for your product? Harvard Business Review, 75 (2), 105-116.

Forrester, J., 1961. Industrial Dynamics. Cambridge MA: MIT Press

Fuller, J.B., O'Conor, J. and Rawlinson, R., 1993. Tailored logistics: the next advantage. Harvard Business Review, 71 (3), 87-98.

Geary, S., Disney, S.M. and Towill, D.R., 2006. On Bullwhip in Supply Chains Historical Review, Present Practice and Expected Future Impact. International Journal of Production Economics, 101, 2-18.

Grünwald, H.J. and Fortuin, L., 1992. Many steps towards zero inventory. European Journal of Operational Research, 59, 359-369.

Hejazi, A. and Hilmola, O., 2006. Manufacturing lot size as a source of the bullwhip effect: a case study of electronic and furniture supply chains. International Journal of Services and Operations Management, 2 (3), 237-255.

Holland, W. and Sodhi, M.S., 2004. Quantifying the effect of batch size and order errors on the bullwhip effect using simulation. International Journal of Logistics: Research and Applications, 7 (3), 251-261. 
Holmström, J., 1997. Product range management: A case study of supply chain operations in the European grocery industry. Supply Chain Management: An International Journal, 2 (3), 107-115.

Iyer, A.V. and Jain, A., 2003. The logistics impact of a mixture of order-streams in a manufacturer-retailer system. Management Science, 49 (7), 890-906.

Kelle, P. and Milne, A., 1999. The effect of $(s, S)$ ordering policy on the supply chain. International Journal of Production Economics, 59 (1-3), 113-122.

Kimura, O. and Terada, H., 1981. Design and analysis of a pull system, a method of multistage production control. International Journal of Production Research, 19 (3), 241-253.

Lee, H.L., Padmanabhan, V. and Whang, S., 1997. The bullwhip effect in supply chains. Sloan Management Review, 38 (3), 93-102.

Metters, R, 1997. Quantifying the Bullwhip Effect in Supply Chains. Journal of Operations Management, 15 (2), 89-100.

Naim, M.M., Childerhouse, P., Disney, S.M. and Towill, D.R., 2002. A supply chain diagnostic methodology: determining the vector of change. Computers and Industrial Engineering, 43 (1-2), 135-157.

Parnaby, J., 1988. A systems approach to the implementation of JIT methodologies in Lucas Industries. International Journal of Production Research, 26 (3), 483-492.

Patton, M.Q., 2002. Qualitative Research and Evaluation Methods. 3rd Edition. London: Sage Publications.

Potter, A.T. and Disney, S.M., 2006. Bullwhip and batching: An exploration. International Journal of Production Economics, 104, 408-418.

Pujawan, I.N., 2004. The effect of lot sizing rules on order variability. European Journal of Operational Research, 159 (3), 617-635.

Stuart, I., McCutcheon, D., Handfield, R.B., McLachlin, R. and Samson, D., 2002. Effective case research in operations management: a process perspective. Journal of Operations Management, 20 (5), 419-433.

Towill, D.R., 1992. Supply chain dynamics - the change engineering challenge of the mid 1990s. Proceedings of the Institution of Mechanical Engineers, 206, 233-245.

Towill, D.R., 1997. Forridge - Principles of good practice in material flow.

Production Planning and Control, 8 (7), 622-632.

Towill, D.R., 1996. Industrial dynamics modelling of supply chains. International Journal of Physical Distribution and Logistics Management, 26 (2), 23-42. 
Towill, D.R., Zhou, L. and Disney, S.M., 2007. Reducing the bullwhip effect: Looking through the appropriate lens. International Journal of Production Economics, $108,444-453$.

van Donk, D.P. and van der Vaart, T., 2005. A case of shared resources, uncertainty and supply chain integration in the process industry. International Journal of Production Economics, 96, 97-108.

Warburton, R.D.H. and Stratton, R., 2002. Questioning the relentless shift to offshore manufacturing. Supply Chain Management: An International Journal, 7 (2), 101-108.

Womack, J.P. and Jones, D.T., 1996. Lean Thinking. New York: Simon and Schuster, N.Y.

Wong, C.Y., Arlbjørn, J.S., Hvolby, H.-H. and Johansen, J., 2006. Assessing responsiveness of a volatile and seasonal supply chain: A case study. International Journal of Production Economics, 104 (2), 709-721.

Wong, C.Y., Arlbjørn, J.S. and Johansen, J., 2005. Supply chain management practices in toy supply chains. Supply Chain Management: An International Journal, $10(5), 367-378$.

Wong, C.Y. and Johansen, J., 2006. Making JIT retail a success: the coordination journey. International Journal of Physical Distribution and Logistics Management, $36(2), 112-126$. 


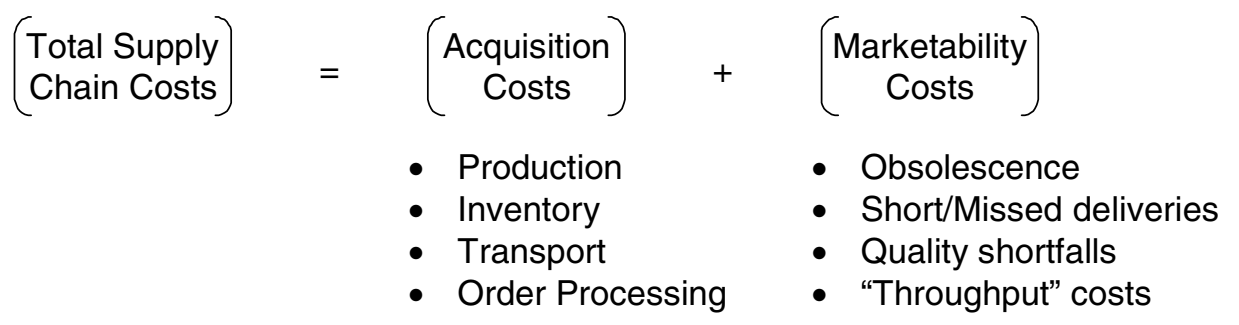

Figure 1. Typical supply chain cost sources (adapted from Fisher, 1997) 


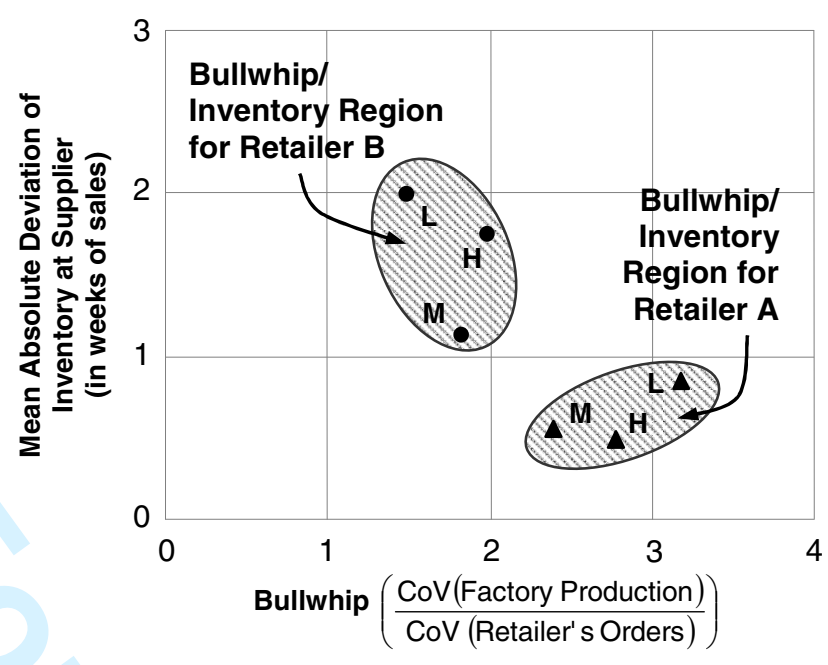

$\mathrm{H}=$ High Volume, $\mathrm{M}=$ Medium Volume, $\mathrm{L}=$ Low Volume

Figure 2. Bullwhip and inventory variance for the soft drinks manufacturer 


\section{Retailer A}

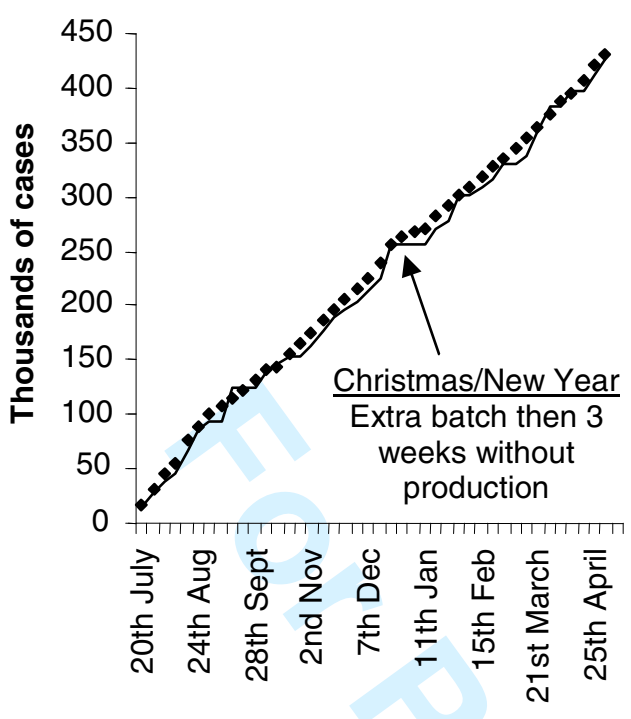

\section{Retailer B}

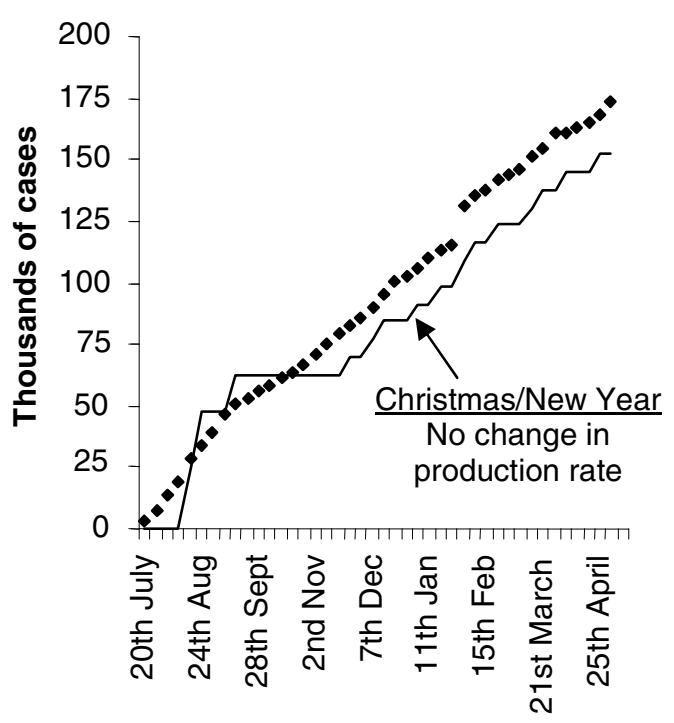

- Retailer Order — Production

Figure 3. Cusum graphs for the high volume soft drinks products 


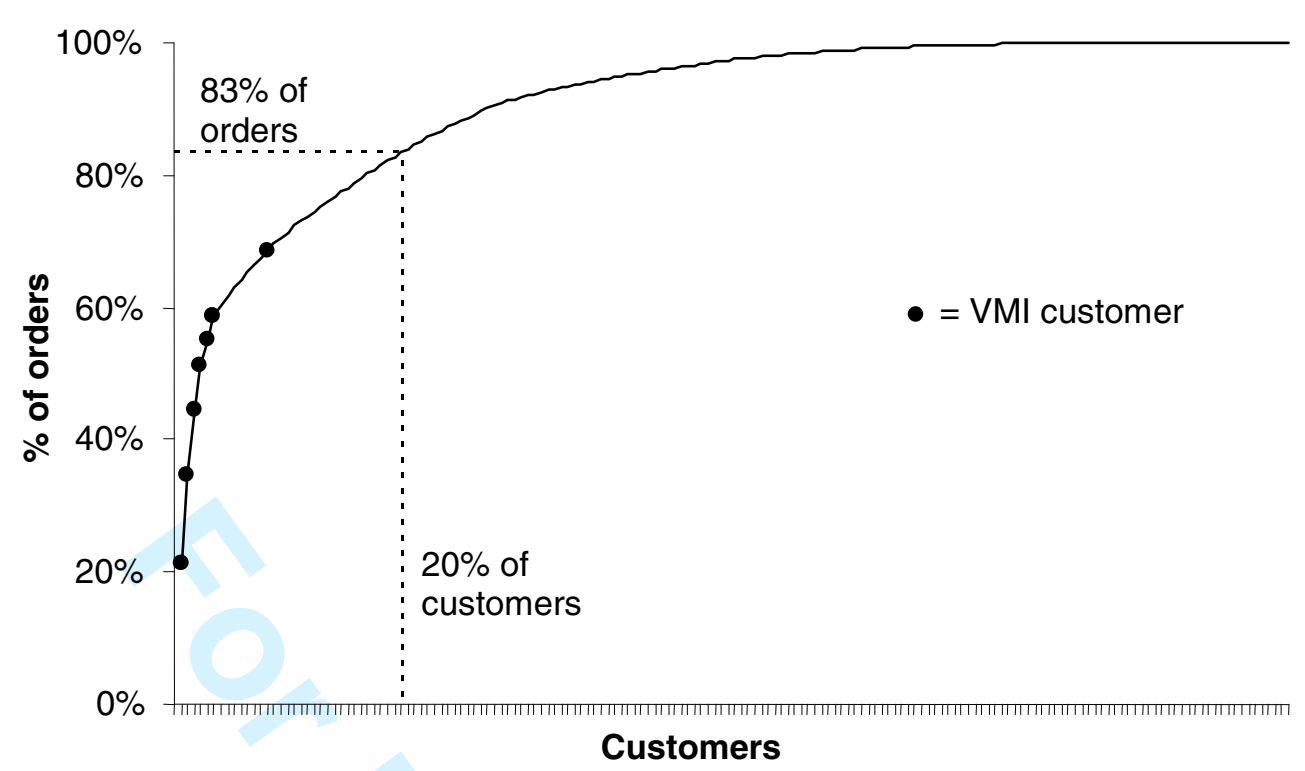

Figure 4. Pareto analysis of demand volumes for tinned vegetable supplier 


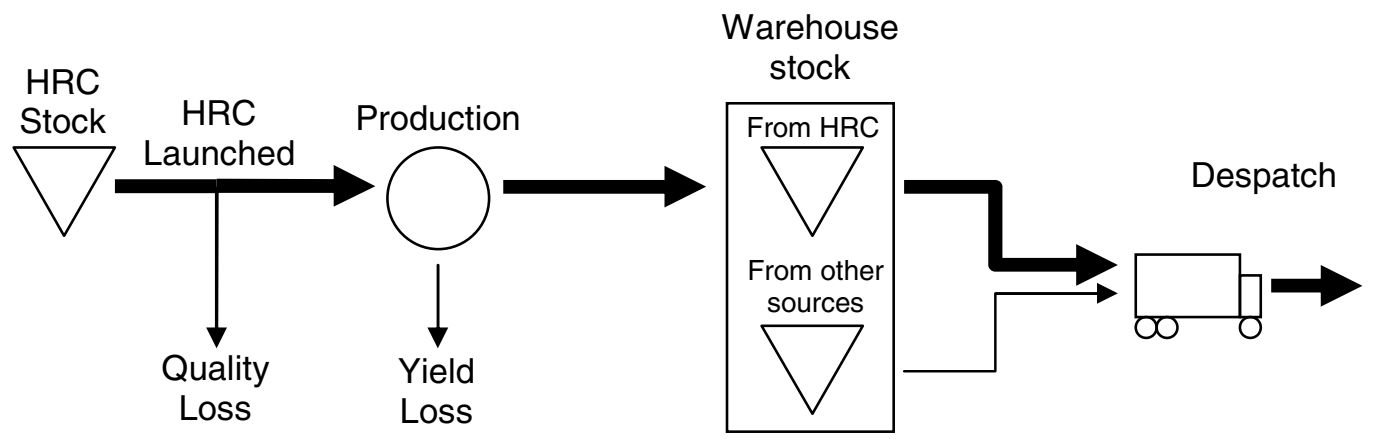

Figure 5. Product flow within the steel producer 


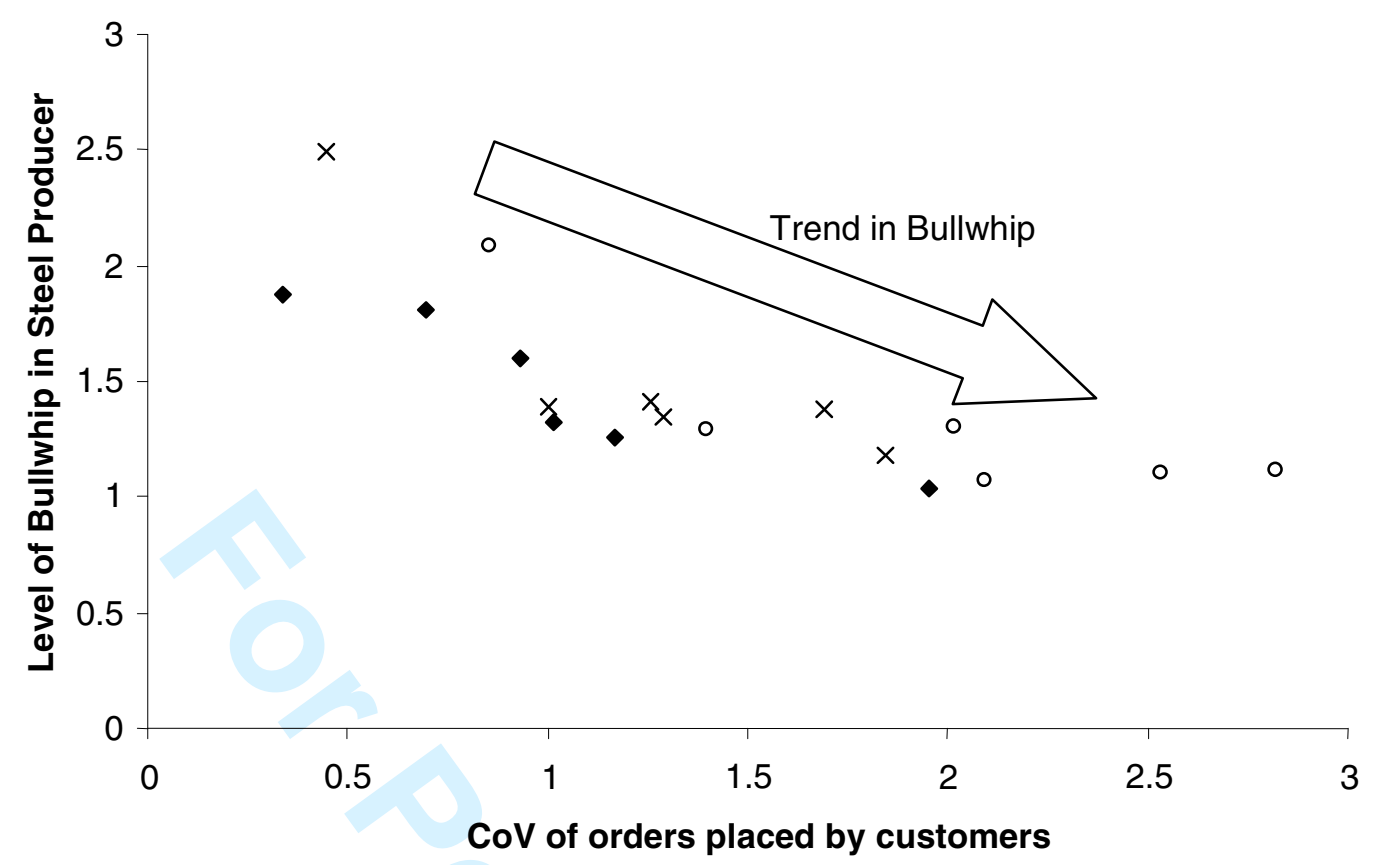

- High Volume Products $\times$ Medium Volume Products $\circ$ Low Volume Products

Figure 6. Comparison of demand variability and bullwhip within the steel producer 
Table 1. Some production scheduling induced bullwhip phenomena (Based on the experiential evidence of Burbidge, 1984)

\begin{tabular}{|c|c|}
\hline Phenomenon & Description \\
\hline Interference Effect & $\begin{array}{l}\text { - When a number of different items share the same value steam there can be } \\
\text { interference if they need to use the same process. } \\
\text { - Such interference causes an increase in throughput time leading to much } \\
\text { greater WIP. } \\
\text { - Typically group technology can assist identification of capacity } \\
\text { "bottlenecks" for system/product re-design. }\end{array}$ \\
\hline Surge Effect & $\begin{array}{l}\text { - If different items are ordered with frequencies the peaks and troughs of the } \\
\text { various parts drift into and out of phase with time. } \\
\text { - Such behaviour causes unpredictable surges (rises and falls) in both stocks } \\
\text { and lead times. } \\
\text { - This effect can be greatly reduced by changing from multi-cycle to single- } \\
\text { cycle production control. }\end{array}$ \\
\hline Industrial Dynamics Effect & $\begin{array}{l}\text { - There is a progressive increase in demand variation and stock level } \\
\text { deviations when a flow or materials is regulated by "traditional stock } \\
\text { control". } \\
\text { - Such amplification results from reliance on EBQ type re-order levels } \\
\text { triggering demand. } \\
\text { - This effect be substantially reduced by moving to a time-based system. }\end{array}$ \\
\hline
\end{tabular}


Table 2. Product categorisation within Lego (Adapted from Wong, et al., 2006)

\begin{tabular}{cccccc}
\hline $\begin{array}{c}\text { Product } \\
\text { Cluster at } \\
\text { Lego }\end{array}$ & $\begin{array}{c}\text { Phase of } \\
\text { Product Life } \\
\text { Cycle }\end{array}$ & $\begin{array}{c}\text { \% of } \\
\text { Product } \\
\text { Lines }\end{array}$ & $\begin{array}{c}\% \text { of } \\
\text { Sales }\end{array}$ & Frequency of Production & $\begin{array}{c}\text { Target order } \\
\text { fill rate }\end{array}$ \\
\hline A & Growth & 5 & 19 & $\begin{array}{c}\text { Twice per month, priority in } \\
\text { production }\end{array}$ & $95 \%$ \\
B & $\begin{array}{c}\text { Maturity/ } \\
\text { Saturation } \\
\text { Saturation/ } \\
\text { Decline }\end{array}$ & 30 & 49 & No details provided & $85 \%$ \\
C & 61 & 29 & Produced every 1 to 2 months & $70 \%$ \\
\hline
\end{tabular}


Table 3. Data sources collected from each Quick Scan

\begin{tabular}{|c|c|c|c|}
\hline \multirow{2}{*}{$\begin{array}{c}\text { QSAM } \\
\text { Tool }\end{array}$} & \multicolumn{3}{|c|}{ Case Study } \\
\hline & UK Grocery & NZ Grocery & UK Steel \\
\hline $\begin{array}{l}\text { Process } \\
\text { mapping }\end{array}$ & $\begin{array}{l}\text { - Information flow from } \\
\text { order generation at } \\
\text { customer to production } \\
\text { planning. } \\
\text { - Physical flow from } \\
\text { production to despatch. }\end{array}$ & $\begin{array}{l}\text { - Information flow from } \\
\text { order receipt or order } \\
\text { generation to raw } \\
\text { material ordering. } \\
\text { - Physical flow from raw } \\
\text { material stock to despatch }\end{array}$ & $\begin{array}{l}\text { Information flow from } \\
\text { order receipt to raw } \\
\text { material ordering. } \\
\text { - Physical flow from raw } \\
\text { material stock to } \\
\text { despatch }\end{array}$ \\
\hline $\begin{array}{l}\text { Archival } \\
\text { data }\end{array}$ & $\begin{array}{l}\text { - Orders received } \\
\text { - Production } \\
\text { - Delivery Performance } \\
\text { - Despatches }\end{array}$ & $\begin{array}{l}\text { - Orders received } \\
\text { - Production } \\
\text { - Delivery performance } \\
\text { - Inventory } \\
\text { - Despatches }\end{array}$ & $\begin{array}{l}\text { - Orders received } \\
\text { - Production } \\
\text { - Delivery performance } \\
\text { - Raw material used }\end{array}$ \\
\hline Interviews & $\begin{array}{l}\text { - Production planning } \\
\text { - Forecasting } \\
\text { - Logistics } \\
\text { - Customer service }\end{array}$ & $\begin{array}{l}\text { - Production planning } \\
\text { - Forecasting } \\
\text { - Logistics } \\
\text { - Supply chain } \\
\text { - Purchasing } \\
\text { - Warehouse }\end{array}$ & $\begin{array}{l}\text { - Production Planning } \\
\text { - Logistics } \\
\text { - Customer service }\end{array}$ \\
\hline
\end{tabular}


Table 4. Comparison of VMI and non-VMI supply chain

\begin{tabular}{|c|c|c|}
\hline & VMI & Non-VMI \\
\hline Number of customers & 7 & 27 \\
\hline \multicolumn{3}{|l|}{$\mathrm{CoV}$ of orders } \\
\hline Minimum & 0.598 & 0.799 \\
\hline Maximum & 1.441 & 5.310 \\
\hline Average & 0.913 & 1.958 \\
\hline $\mathrm{CoV}$ of production & \multicolumn{2}{|c|}{1.042} \\
\hline Bullwhip $^{a}$ & 1.141 & 0.532 \\
\hline
\end{tabular}


Table 5. Supply chain data for exemplar products from the steel producer

\begin{tabular}{|c|c|c|c|c|c|c|c|c|c|c|}
\hline \multirow[t]{2}{*}{ Customer } & \multirow[b]{2}{*}{ Product } & \multirow{2}{*}{$\begin{array}{c}\text { Total Orders } \\
\text { (tonnes) }\end{array}$} & \multicolumn{2}{|c|}{ Average Tonnes/week } & \multicolumn{2}{|c|}{ Coefficient of Variation } & \multirow[b]{2}{*}{ Bullwhip } & \multicolumn{2}{|c|}{ \% Despatches From } & \multirow{2}{*}{$\begin{array}{c}\% \text { of tonnes held in } \\
\text { warehouse over } 1 \\
\text { week }^{\mathrm{a}}\end{array}$} \\
\hline & & & Ordered & HRC launched & Orders & HRC launched & & HRC & $\begin{array}{c}\text { Other } \\
\text { sources }\end{array}$ & \\
\hline \multicolumn{11}{|l|}{ High Volume } \\
\hline \multirow[t]{3}{*}{ Customer X } & A & 13721 & 136 & 134 & 0.70 & 1.26 & 1.81 & 78 & 22 & 70 \\
\hline & $\mathrm{B}$ & 8795 & 87 & 132 & 1.17 & 1.47 & 1.26 & 93 & 7 & 58 \\
\hline & $\mathrm{C}$ & 6269 & 64 & 72 & 0.93 & 1.49 & 1.59 & 80 & 20 & 27 \\
\hline \multirow[t]{3}{*}{ Customer Y } & $\mathrm{D}$ & 20146 & 201 & 212 & 1.01 & 1.34 & 1.32 & 79 & 21 & 27 \\
\hline & $\mathrm{E}$ & 4688 & 188 & 256 & 0.34 & 0.64 & 1.88 & 99 & 1 & 19 \\
\hline & $\mathrm{F}$ & 3676 & 53 & 64 & 1.95 & 2.01 & 1.03 & 100 & 0 & 18 \\
\hline \multicolumn{11}{|c|}{ Medium Volume } \\
\hline \multirow[t]{3}{*}{ Customer X } & $\mathrm{G}$ & 2880 & 42 & 48 & 0.44 & 1.11 & 2.49 & 86 & 14 & 55 \\
\hline & $\mathrm{H}$ & 2099 & 28 & 31 & 1.26 & 1.77 & 1.41 & 63 & 37 & 45 \\
\hline & I & 1067 & 16 & 16 & 1.69 & 2.33 & 1.38 & 71 & 29 & 54 \\
\hline \multirow{3}{*}{ Customer Y } & $\mathrm{J}$ & 2007 & 51 & 99 & 1.00 & 1.39 & 1.39 & 97 & 3 & 27 \\
\hline & $\mathrm{K}$ & 1922 & 21 & 30 & 1.84 & 2.17 & 1.18 & 98 & 2 & 40 \\
\hline & $\mathrm{L}$ & 1569 & 56 & 71 & 1.29 & 1.73 & 1.34 & 91 & 9 & 49 \\
\hline \multicolumn{11}{|l|}{ Low Volume } \\
\hline \multirow[t]{3}{*}{ Customer X } & M & 977 & 13 & 19 & 2.54 & 2.79 & 1.10 & 100 & 0 & 76 \\
\hline & $\mathrm{N}$ & 488 & 9 & 10 & 2.09 & 2.23 & 1.06 & 75 & 25 & 46 \\
\hline & $\mathrm{O}$ & 407 & 9 & 5 & 2.02 & 2.63 & 1.30 & 40 & 60 & 83 \\
\hline \multirow[t]{3}{*}{ Customer Y } & $\mathrm{P}$ & 1139 & 76 & 49 & 0.86 & 1.78 & 2.08 & 39 & 61 & 90 \\
\hline & $\mathrm{Q}$ & 807 & 24 & 33 & 1.40 & 1.80 & 1.29 & 95 & 5 & 60 \\
\hline & $\mathrm{R}$ & 494 & 11 & 13 & 2.82 & 3.14 & 1.11 & 100 & 0 & 24 \\
\hline
\end{tabular}

${ }^{a}$ Only steel that was manufactured according to schedule 
Table 6. The Acquisition Cost/Mediation Cost Ratio

\begin{tabular}{|c|c|c|c|}
\hline Cost Relationship & $\begin{array}{c}\text { UK } \\
\text { Grocery }\end{array}$ & $\begin{array}{c}\text { NZ } \\
\text { Grocery }\end{array}$ & UK Steel \\
\hline Acquisition Costs Much Greater Than Mediation Costs & & & $\checkmark$ \\
\hline Acquisition Costs Greater Than Mediation Costs & \multicolumn{3}{|c|}{$\checkmark$} \\
\hline \multicolumn{4}{|l|}{ Acquisition Costs Less Than Mediation Costs } \\
\hline Acquisition Costs Much Less than Mediation Costs & $\checkmark$ & & \\
\hline
\end{tabular}


Table 7. Comparison of total supply chain costs for the three cases

\begin{tabular}{|c|c|c|c|}
\hline Case & Acquisition Costs & Marketability Costs & Implications for Bullwhip \\
\hline $\begin{array}{l}\text { UK } \\
\text { Grocery }\end{array}$ & $\begin{array}{l}\text { - Production - slightly higher for Retailer B due to } \\
\text { half batches and speed of adaptation costs. } \\
\text { - Inventory - Supplier works to } 1.5 \text { weeks safety } \\
\text { stock, with an opportunity cost associated with } \\
\text { demand variability. } \\
\text { - Transport - Transport costs per mile are } 6 \% \\
\text { higher for Retailer B. } \\
\text { - Order processing - Greater for Retailer A supply } \\
\text { chain as VMI requires one person full time. }\end{array}$ & $\begin{array}{l}\text { - Obsolescence - Not an issue as products are } \\
\text { relatively fast moving and have long shelf life. } \\
\text { - } \frac{\text { Short/missed deliveries - Large fines from both }}{\text { retailers for stockouts. }} \\
\text { - Quality shortfalls - Supplier bears the cost of } \\
\text { customer returns. } \\
\text { - "Throughput costs" - Retailer A accounts for } \\
\text { 30\% of total volume, so supplier does not want to } \\
\text { lose their business. }\end{array}$ & $\begin{array}{l}\text { - Marketability costs are much greater than } \\
\text { acquisition costs. } \\
\text { - Accept higher acquisition costs to offset the risk of } \\
\text { incurring marketability costs. } \\
\text { - Different pipeline control to make best use of } \\
\text { assets. } \\
\text { - Greater bullwhip for Retailer A, because of greater } \\
\text { visibility and flexibility. } \\
\text { - Less bullwhip for Retailer B, but offset by higher } \\
\text { inventory variance. } \\
\text { - Key internal factors affecting bullwhip: } \\
\text { Production batch size, capacity allocation for } \\
\text { customers, VMI control }\end{array}$ \\
\hline $\begin{array}{l}\text { NZ } \\
\text { Grocery }\end{array}$ & $\begin{array}{l}\text { - Production - Volume driven with batching of } \\
\text { orders to achieve economy of scale } \\
\text { - Inventory - High inventory at factory. Reduced } \\
\text { retailer inventory for VMI } \\
\text { - Transport - Similar cost per mile for both as both } \\
\text { can obtain good vehicle fill. Milk Runs. } \\
\text { - Order processing - Greater for VMI as it requires } \\
\text { one person full time per customer. }\end{array}$ & $\begin{array}{l}\text { - Obsolescence - Not an issue as product is } \\
\text { relatively fast moving with a long shelf live. Long } \\
\text { Product Life Cycle } \\
\text { - Short/missed deliveries - Current delivery } \\
\text { performance suggest that this is not an issue } \\
\text { - Quality shortfalls - Focal company bears the cost } \\
\text { of customer returns, however hardly an issue } \\
\text { - "Throughput costs" - VMI customers account for } \\
\text { nearly } 60 \% \text { of volume }\end{array}$ & $\begin{array}{l}\text { - Marketability costs are slightly greater than } \\
\text { acquisition costs. } \\
\text { - Orders are batched to provide economies of scale, } \\
\text { although this results in higher inventory costs. } \\
\text { - Greater bullwhip for VMI due to aggregation of } \\
\text { demand. } \\
\text { - Key internal factors affecting bullwhip: } \\
\text { Production batch size, capacity allocation for } \\
\text { products, VMI control }\end{array}$ \\
\hline UK Steel & 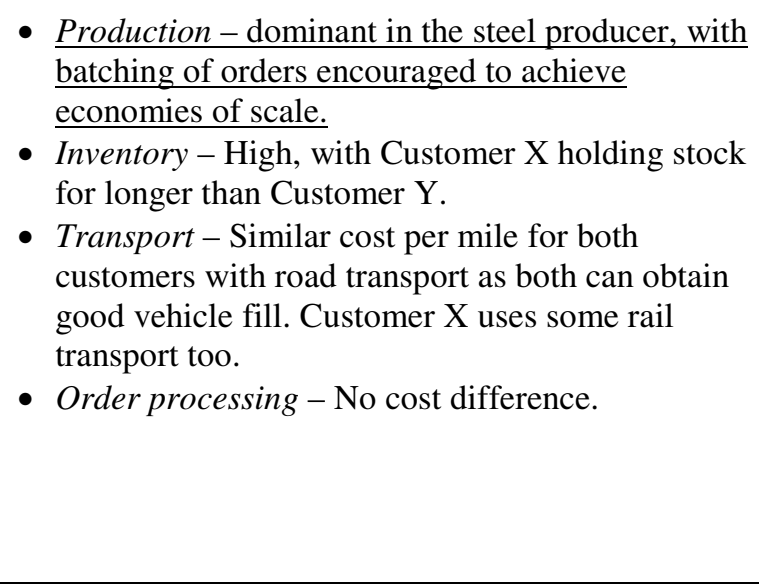 & $\begin{array}{l}\text { - Obsolescence - Not an issue providing steel is } \\
\text { stored under cover. } \\
\text { - Short/missed deliveries - Current delivery } \\
\text { performance suggests this is not a major issue for } \\
\text { customers. Material can be transferred from other } \\
\text { products. } \\
\text { - Quality shortfalls - Production yield is accounted } \\
\text { for by 'launching' more steel than is ordered. } \\
\text { - "Throughput costs" - Customer X accounts for } \\
\text { almost } 50 \% \text { of total volume so tends to receive } \\
\text { priority in planning. }\end{array}$ & $\begin{array}{l}\text { - Steel is a commodity product therefore acquisition } \\
\text { costs are more important than marketability costs. } \\
\text { - Regular orders are batched to provide production } \\
\text { economies. } \\
\text { - This is useful as current technology does not } \\
\text { permit production in smaller batches. } \\
\text { - Customers over-order and extra material is } \\
\text { launched to account for yield losses, resulting in } \\
\text { higher inventory costs. } \\
\text { - By including yield loss, there appears to be some } \\
\text { reduction in bullwhip. } \\
\text { - Key internal factors affecting bullwhip: } \\
\text { Production batch size, capacity allocation for } \\
\text { customers }\end{array}$ \\
\hline
\end{tabular}


Table A1. Profile of the retailers and products studied in the UK grocery case study

\begin{tabular}{lcc}
\hline & VMI Retailer & Non-VMI Retailer \\
\hline General Information & & \\
Annual sales from case study & 9.0 million cases & 3.3 million cases \\
Number of different products & 200 & 130 \\
Delivery point & Retailer DC & Retailer DC \\
High Volume Product & & \\
Type of product & Cherryade & Lemonade \\
Annual sales (cases) & 535,000 & 265,000 \\
Amplification at manufacturer & 2.78 & 1.99 \\
Medium Volume Product & & \\
Type of product & Orangeade & Cherryade \\
Annual sales (cases) & 442,000 & 117,000 \\
Amplification at manufacturer & 2.40 & 1.83 \\
Low Volume Product & & \\
Type of product & Strawberryade & Cream Soda \\
Annual sales (cases) & 133,000 & 54,000 \\
Amplification at manufacturer & 3.17 & 1.49 \\
\hline
\end{tabular}


Figure 1. Typical supply chain cost sources (adapted from Fisher, 1997)

Figure 2. Bullwhip and inventory variance for the soft drinks manufacturer

Figure 3. Cusum graphs for the high volume soft drinks products

Figure 4. Pareto analysis of demand volumes for tinned vegetable supplier

Figure 5. Product flow within the steel producer

Figure 6. Comparison of demand variability and bullwhip within the steel producer

Table 1. Some production scheduling induced bullwhip phenomena (Based on the experiential evidence of Burbidge, 1984)

Table 2. Product categorisation within Lego (Adapted from Wong, et al., 2006)

Table 3. Data sources collected from each Quick Scan

Table 4. Comparison of VMI and non-VMI supply chain

Table 5. Supply chain data for exemplar products from the steel producer

Table 6. The Acquisition Cost/Mediation Cost Ratio

Table 7. Comparison of total supply chain costs for the three cases

Table A1. Profile of the retailers and products studied in the UK grocery case study 